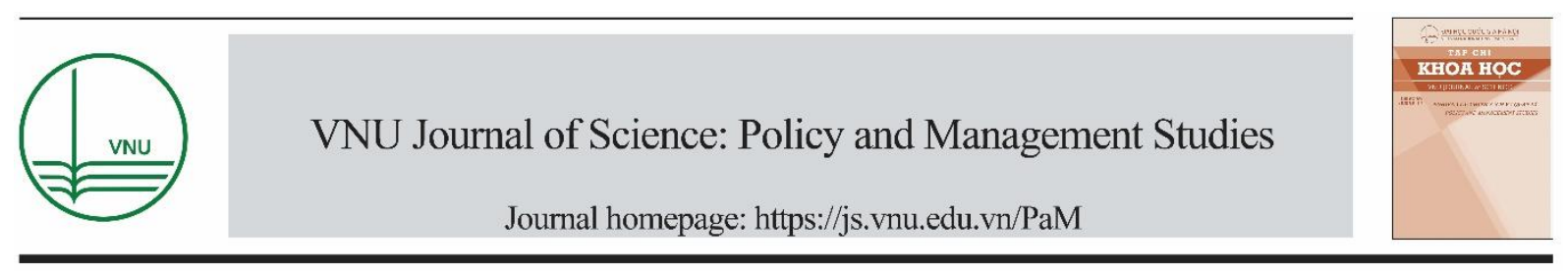

Review Article

\title{
University Endowment Funds in the United States and the Application in Vietnam
}

\author{
Le Thi Thu Ha*, Ho Nhat Le \\ Foreign Trade University, 91 Chua Lang, Hanoi, Vietnam \\ Received 16 September 2020 \\ Revised 29 October 2020; Accepted 30 October 2020
}

\begin{abstract}
Endowment funds or charitable gifts first appeared back in the period of Roman Empire, yet have become a real success only since universities in the United States established and developed them with a progressive management mindset. Endowment funds assure income stability and leverage new sources of revenue. The present research sheds light on the two popular models of university endowment funds in the United States taking into account the advantages and disadvantages of university endowment establishment in Vietnam. Also, suggestions for the application in Vietnam are provided.
\end{abstract}

Keywords: Endowment fund, university education.

\footnotetext{
${ }^{*}$ Corresponding author.

Email address: ha.le@ftu.edu.vn
}

https://doi.org/10.25073/2588-1116/vnupam.4268 


\title{
Mô hình quỹ tín thác trường đại học Hoa Kỳ và khả năng áp dụng tại các trường đại học Việt Nam
}

\author{
Lê Thị Thu Hà*, Hồ Nhật Lệ \\ Truờng Đại học Ngoại thuoong, 91 Chùa Láng, Hà Nội, Việt Nam \\ Nhận ngày 16 tháng 9 năm 2020 \\ Chỉnh sửa ngày 29 tháng 10 năm 2020; Chấp nhận đăng ngày 30 tháng 10 năm 2020
}

\begin{abstract}
Tóm tắt: Quỹ tín thác hay quỹ quyên tặng xuất hiện đầu tiên từ đế chế La Mã nhưng chỉ thực sự thành công khi các trường đại học của Hoa Kỳ xây dựng và phát triển nó với tư duy quản trị tiên tiến. Quỹ tín thác tạo ra sự ổn định về nguồn thu và đòn bẩy cho các nguồn thu khác đáp ứng những mục tiêu dài hạn của tổ chức. Nghiên cứu hai mô hình tiêu biểu về quỹ tín thác tại Hoa Kỳ và đánh giá những thuận lợi và khó khăn khi áp dụng vào các trường đại học ở Việt Nam. Bài viết cũng đề xuất các giải pháp nhằm triển khai mô hình quỹ tín thác tại các trường đại học của Việt Nam
\end{abstract}

Tù̀ khóa: Quỹ tín thác, giáo dục đại học.

\section{Mở đầu}

Quỹ tín thác trường đại học (university endowment) xuất hiện ở Anh từ khoảng thế kỷ XV đến thế kỷ XVI [1] và thực sự được phát triển, hoàn thiện trong các cơ sở giáo dục bậc cao tại Hoa Kỳ [2]. Nhiều tổ chức phi lợi nhuận khác ở Hoa Kỳ cũng đã triển khai và duy trì các quỹ tín thác, điển hình là các nhà thờ, bệnh viện, bảo tàng, trường trung học tư thục và các nhóm văn hóa và nghệ thuật biểu diễn [3]. Tuy nhiên, thành công nhất vẫn là mô hình quỹ tín thác của các trường đại học, đặc biệt là các trường thuộc khối Ivy League như Harvard, Yale hay Stanford và đã dẫn đầu trong lĩnh vực đầu tư đa tài sản trong hơn hai thập kỷ với giá trị lên đến hàng chục tỷ USD [4]. Nguồn lợi nhuận thu được từ hoạt động đầu tư của các quỹ tín thác đang dần trở thành nguồn tài chính trọng yếu cho sự vận hành của các trường đại học [5]. Thành công trong cách thức xây dựng, huy động, quản lý, đầu tư và chi tiêu của các quỹ tín thác trường đại học Hoa Kỳ không chỉ thu hút sự quan tâm của các tổ chức phi lợi nhuận, các mô hình giáo dục tự chủ mà còn nhận được nhiều sự chú ý từ các định chế đầu tư tài chính [6].

Tại Việt Nam, tự chủ trong giáo dục, đặc biệt là trong giáo dục bậc cao đang được đẩy mạnh. Ý tưởng về việc xây dựng mô hình đại học tự chủ đã được Thủ Tướng Chính phủ nêu ra trong Quyết định số $153 / 2003 /$ QĐ-TTg vào 2003: “...Trường đại học được quyền tự chủ và tự chịu trách nhiệm theo quy định của pháp luật về quy hoạch, kế hoạch phát triển nhà trường, tổ chức các hoạt động đào tạo, khoa học, công nghệ, tài chính, quan hệ quốc tế, tổ chức và nhân sự". Nghi quyết 14/2005/NQ-CP của Chính Phủ ban hành "Về việc đổi mới cơ bản và toàn diện giáo dục đại học Việt Nam giai đoạn 2006 2020" một lần nữa nhấn mạnh việc đổi mới cơ chế quản lý này. Theo đó, các cơ sở giáo dục đại học công lập sẽ chuyển sang hoạt động theo cơ chế tự chủ, có pháp nhân đầy đủ, có quyền quyết

\footnotetext{
*Tác giả liên hệ.

Địachiemail: ha.le@ftu.edu.vn

https://doi.org/10.25073/2588-1116/vnupam.4268
} 
định và chịu trách nhiệm về đào tạo, nghiên cứu, tổ chức, nhân sự và tài chính. Điều này cũng được khẳng định trong Luật giáo dục đại học năm 2012. Tuy nhiên, dù đã có được một hành lang pháp lý tương đối hoàn thiện và rõ ràng cho quyền tự chủ ở bậc đại học, việc thay đổi mô hình quản lý bộ máy tài chính, nhân sự và tuyển sinh ở các trường đại học tại Việt Nam vẫn diễn ra khá chậm chạp, nhất là trong vấn đề tự chủ tài chính.

Quỹ tín thác trường đại học liệu có thể trở thành một hướng đi giúp các cơ sở giáo dục bậc cao tại Việt Nam đạt được thế chủ động trong quá trình xây dựng, quản lý, phân bổ nguồn tài chính của mình không ? Nghiên cứu Mô hình quỹ tín thác trương đại học Hoa Kỳ và khả năng áp dụng tại các truoòng đại học Việt Nam phần nào giải đáp cho câu hỏi trên.

\section{Khái niệm}

Quỹ tín thác hay còn gọi là quỹ quyên tặng là các quỹ được tích lũy bởi các tổ chức để hỗ trợ, tài trợ cho các hoạt động của chính tổ chức đó [1]. Quỹ tín thác còn được sử dụng phổ biến trong các tổ chức phi lợi nhuận như bệnh viện, bảo tàng, thư viện, và cả các trường cao đẳng và đại học [3]. Về mặt pháp lý, quỹ tín thác có thể được xây dựng như một bộ phận của một trường đại học, hoặc là một đơn vị riêng biệt của các tổ chức phi lợi nhuận [1].

Trong khuôn khổ giáo dục đại học, các khoản tài trợ là một nguồn thu được các trường cao đẳng hoặc đại học sử dụng để đầu tư và hỗ trợ sứ mệnh giáo dục lâu dài của chính các trường đó [7]. Quỹ tín thác bao gồm hàng trăm hoặc hàng ngàn khoản tài trợ cá nhân, cho phép các nhà tài trợ đầu tư các nguồn tài chính cá nhân, riêng lẻ cho các mục đích công với sự đảm bảo rằng tài trợ của họ sẽ phục vụ các mục đích dài lâu của tổ chức trong điều kiện tồn tại vĩnh viễn. Quỹ tín thác trường đại học cho phép hiện thực hóa các cam kết trong tương lai vì nó tạo ra các nguồn lực để đáp ứng những yêu cầu sẳn có ở hiện tại [8].
Quỹ tín thác là một tổ chức đầu tư được điều chỉnh trong nhiều bộ luật của các quốc gia phát triển, trong đó điển hình là Luật thuế thu nhập của Hoa Kỳ (Income Tax Act § 149.1(2)(b)). Đến nửa sau của thế kỷ XX, khi hoạt động của các quỹ tín thác trường đại học Hoa Kỳ trở nên phổ biến, nhiều nghiên cứu về mô hình, cách thức gây quỹ và hiệu quả tài chính của quỹ tín thác trường đại học được tiến hành với mục tiêu tạo ra một dòng thu nhập thực tế dự kiến dài hạn. Cách thức tài trợ giáo dục này trở thành một tiêu điểm trong cả lĩnh vực giáo dục và đầu tư.

\section{Vai trò của quỹ tín thác}

Bàn về mô hình quỹ tín thác trường đại học, Hansmann (1990) [1] đã đề cập đến những lợi ích của mô hình quỹ tín thác trường đại học, trong đó nhấn mạnh tính hiệu quả, tầm quan trọng của việc triển khai cũng như các dạng thức đầu tư để đạt lợi nhuận tối đa. Tiếp đó, Merton (1993) [8] đã dành một chương để phân tích và bàn luận về các chiến lược đầu tư tối ưu cho quỹ tín thác trường đại học. Bằng việc xây dựng các hàm tuyến tính với các biến số là các hoạt động của trường đại học như giáo dục, đào tạo, đầu tư và nghiên cứu cùng các tiêu chí xếp loại trường như số lượng sinh viên và tổng giá trị quỹ tín thác, Merton (1993) [8] đã rút ra những ảnh hưởng của nguồn lực tài chính của bản thân ngôi trường và việc sử dụng tài sản thay thế lên mức độ thành công của các quỹ tín thác trường đại học Hoa Kỳ. Gần đây hơn, Fishman (2014) [9] đã xem xét khuôn khổ pháp lý cho mô hình đầu tư quỹ tín thác trường đại học, chính sách đầu tư tài trợ, sự phát triển của chúng đối với các điều kiện phức tạp hơn và rủi ro hơn.

Nhìn chung, các nghiên cứu đều ghi nhận quỹ tín thác phục vụ các tổ chức và cộng đồng bằng cách:

\section{i) Tạo ra sự ổn định về nguồn thu}

Doanh thu của trường cao đẳng và đại học dao động theo thời gian với những thay đổi trong học phí, số tiền tài trợ và hỗ trợ công cộng. Đối với quỹ tín thác, số tiền gốc luôn được bảo lưu và chỉ tiền lãi được ưu tiên sử dụng cho giáo dục 
vì vậy tạo ra nguồn thu ổn định để cho cho hỗ trợ sinh viên, giảng viên, chương trình học tập sáng tạo, nghiên cứu y tế và thư viện.

\section{ii) Tạo đòn bẩy cho các nguồn thu khác}

Trong những năm gần đây, khi nền kinh tế đang trong tình trạng bất ổn, các cơ sở giáo dục phải tăng đáng kể chi tiêu hỗ trợ cho sinh viên. Trong bối cảnh đó, các trường đại học, cao đẳng sở hữu các quỹ tín thác giá trị lớn nhất cũng là những trường có nhiều khả năng tiếp nhận sinh viên mà không cần quá quan tâm đển khả năng tài chính, mà còn cung cấp các gói hỗ trợ tài chính cho sinh viên. Khoản hỗ trợ cũng cho phép trường cao đẳng hoặc đại học nâng cao chât lượng dịch vụ đào tạo và với mức chi phí thấp hơn tương đối. Điều này đặc biệt quan trọng đôi với các tổ chức công đã cắt giảm hỗ trợ từ ngân sách của nhà nước. Nếu không có các nguồn tài chính khác bù lại, nhiều tổ chức sẽ phải cắt giảm các chương trình hoạt động của mình, thậm chí là tăng mức học phí lên gấp nhiều lần so với dịch vụ đào tạo, đẩy gánh nặng tài chính lên vai của các bậc phụ huynh và các sinh viên.

\section{hoạt}

iii) Khuyến khích đổi mới và tăng tính linh

Một khoản hỗ trợ trong khuôn khổ quỹ tín thác cho phép giảng viên và sinh viên tiến hành nghiên cứu sáng tạo, khám phá các lĩnh vực học thuật mới, áp dụng các công nghệ mới và phát triển các phương pháp giảng dạy mới ngay cả khi sự tài trợ không có sẵn từ các nguồn khác, bao gồm học phí, quà tặng, hoặc trợ cấp. Sự đổi mới và linh hoạt như vậy dẫn đến những thành tựu hoàn toàn mới các chương trình và những khám phá quan trọng trong khoa học, y học, giáo dục và các lĩnh vực khác.

\section{hạn}

iv) Cho phép đáp úng nhũng mục tiêu dài

Không giống như những món quà được sử dụng khi nhận, quỹ tín thác mang giá trị thời gian. Về lâu dài, chúng không chỉ đem lại lợi nhuận qua hoạt đồng đầu tư, tài trợ, mà quỹ tín thác còn thể hiện danh tiếng, sự gắn kết trong cộng đồng cựu sinh viên, giảng viên. Các cơ sở giáo dục có thể có kế hoạch chiến lược để sử dụng một nguồn thu nhập đáng tin cậy hơn để tăng cường và nâng cao chất lượng của các chương trình của họ, thậm chí có những kế hoạch trong vòng nhiều năm được triển khai. Ví dụ chiến dịch Harvard để kêu gọi vốn cho quỹ tín thác đại học Harvard diễn ra trong vòng 5 năm liên tục và đạt được số tiền tài trợ rất lớn. Bằng cách đóng góp vào quỹ tín thác, cựu sinh viên và những người quyên tặng đã thực hiện trách nhiệm đảm bảo phát triển bền vững cho các trường cao đẳng và đại học; phần góp giúp cho các thế hệ sinh viên tương lai được hưởng lợi một nền giáo dục chất lượng cao hơn và cho phép các tổ chức này đóng góp nhiều hơn cho lợi ích công cộng.

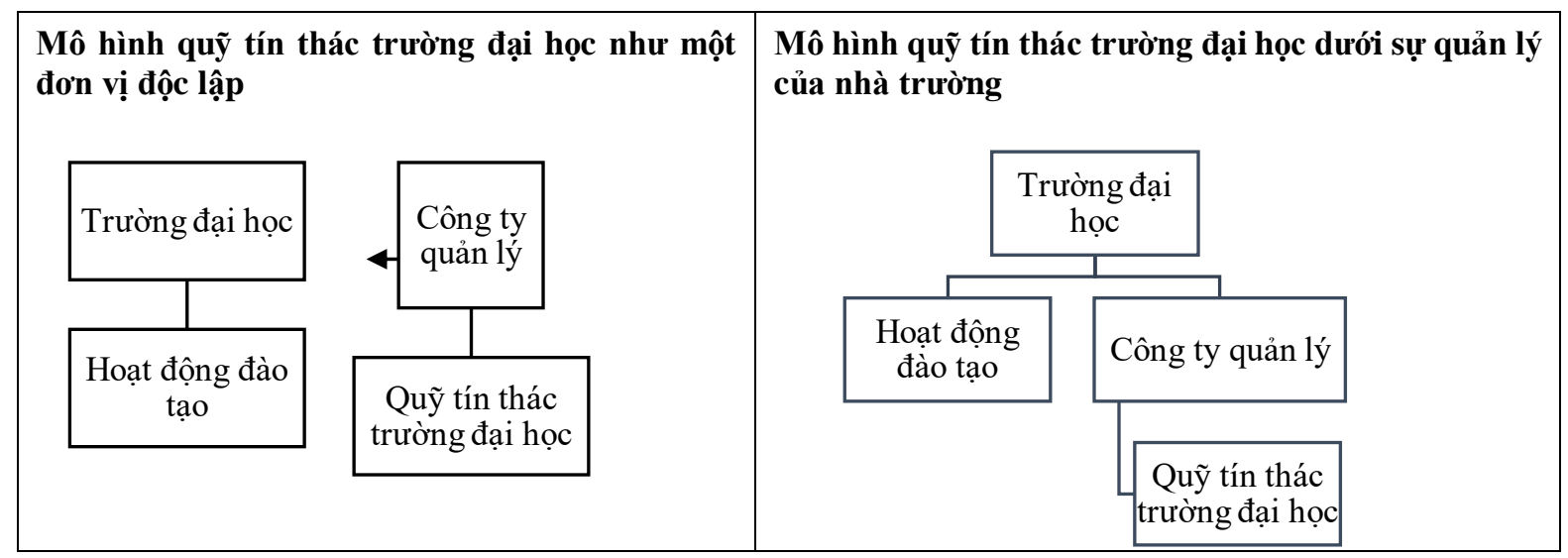

Hình 1. So sánh hai mô hình quỹ tín thác trường đại học phổ biến tại Hoa Kỳ.

Nguồn: Nhóm nghiên cứu 


\section{Mô hình 1: Quỹ tín thác trường đại học như một đơn vị độc lập - Đại học Havard}

Tại nhiều trường đại học, quỹ tín thác được vận hành bởi một đơn vị độc lập với các hoạt động giảng dạy và đào tạo của trường đại học [10]. Công ty quản lý quỹ tín thác có điều lệ, nguyên tắc hoạt động và tổ chức nhân sự tách biệt với khối hành chính và đào tạo.

Nhờ sự độc lập tương đối của đơn vị quản lý, các chương trình và chiến dịch gây quỹ được thực hiện ở một quy mô rộng và hướng đến nhiều đối tượng tài trợ hơn. Thành viên ban điều hành và nhân viên của công ty quản lý quỹ có thể bao gồm cả nhân viên trong trường lẫn những nhà đầu tư tài chính, giúp hoạt động đầu tư đạt hiệu quả cao trong khi chi phí nhân sự không bị tăng quá cao.

Bên cạnh đó, mô hình quỹ tín thác như một đơn vị độc lập cũng có thể gặp rủi ro khi mối liên hệ giữa nhà trường và hội đồng quản trị quỹ gặp vấn đề. Nhìn chung, tài sản và tiền mặt đóng góp cho quỹ tín thác phần lớn đến từ các cựu sinh viên, các tổ chức, công ty và đơn vị tư nhân có mối quan hệ mật thiết với các khoa chuyên môn [11]. Do đó, để gọi được một số vốn đáng kể cho quỹ tín thì cả bộ phận điều hành quỹ và bộ phận sư phạm cần thống nhất mục tiêu, chiến lược và kết hợp nhuần nhuyễn trong quá trình triển khai. Ngoài ra, khi phân bổ chi tiêu quỹ tín thác, ban quản lý quỹ phải cần xem xét kĩ lưỡng, cân nhắc cẩn thận nhu cầu, định hướng phát triển của từng phòng ban, khoa chuyên môn trong trường. Điển hình cho mô hình này là Quỹ tín thác của Đại học Harvard.

Quỹ tín thác của Đại học Harvard là tài sản tài lớn nhất của trường, hỗ trợ lâu dài và bền vững cho sứ mệnh giảng dạy và nghiên cứu của trường. Khoản tín thác của Harvard được tạo thành từ hơn 13.000 quỹ nhỏ hơn nhằm thực hiện hai hoạt động lớn nhất là hỗ trợ khoa chuyên môn và sinh viên, bao gồm đánh giá, nâng cao trình độ giáo sư và hỗ trợ tài chính cho sinh viên đại học, nghiên cứu sinh, cho cuộc sống và các hoạt động của sinh viên.

\section{Cách thức quản lý quỹ tín thác Havard}

Quỹ tín thác Havard được quản lý bởi công ty quản lý Harvard (Harvard Management Company - HMC) - một công ty con phi lợi nhuận thuộc sở hữu của Đại học Harvard. Đây chính là đơn vị đã quản lý danh mục đầu tư của trường từ năm 1974 được điều hành bởi một ban giám đốc gồm Chủ tịch và các Nghiên cứu sinh do Đại học Harvard bổ nhiệm. HMC có một nhiệm vụ duy nhất là tạo ra kết quả đầu tư tích cực để hỗ trợ các mục tiêu giáo dục và nghiên cứu của trường. HMC hoạt động để quản lý nguồn lực một cách bền vững đảm bảo cung cấp vốn cho các mục tiêu dài hạn của Harvard. HMC không chỉ quản lý hoạt động gọi vốn, đầu tư, mà còn phân bồ quỹ tín thác cho các hoạt động của đại học Harvard.

Trên thực tế, chi tiêu của Harvard phải phân bổ cho hai nhu cầu: đảm bảo vận hành ổn định và có kế hoạch và duy trì giá trị dài hạn của tài sản tín thác sau khi hạch toán lạm phát.

HMC giúp Harvard xác định các khoản phân bổ tài trợ hàng năm sau khi xem xét nhiều yếu tố, bao gồm kết quả thu được từ công thức tính toán phân bổ mà đưa ra nguồn thu nhập ổn định để hô̂ trợ các nhu cầu hiện tại trong khi duy trì sức mua trong tương lai.

Bảng 1. Phân bổ quỹ tín thác của Harvard cho những loại tài sản đầu tư và lợi nhuận trong năm 2018 (đơn vị: \%)

\begin{tabular}{|l|l|l|}
\hline Phân loại tài sản & Trọng số phân bố (\%) & Lợi tức thực tế (\%) \\
\hline Vốn chủ sở hữu công & 31 & 14 \\
\hline Vốn chủ sở hữu tư nhân & 16 & 21 \\
\hline Quỹ phòng vệ & 21 & 6 \\
\hline Tài nguyên thiên nhiên & 13 & 9 \\
\hline Trái phiếu & 6 & 2 \\
\hline Tài nguyên thiên nhiên & 8 & 1 \\
\hline Bất động sản và các khoản nợ cá nhân khác & 2 & 1 \\
\hline Tiền mặt & 3 & 0 \\
\hline
\end{tabular}

Nguồn: Báo cáo tài chính Đại học Harvard, 2018 [12] 
Theo nguyên tắc chung, Harvard đặt ra tỷ lệ xuất chi mục tiêu hàng năm từ $5,0 \%$ đến $5,5 \%$ giá trị thị trường. Tỷ lệ xuất chi thực tế của trường đã biến động tương đối mạnh trong 10 năm qua, từ mức thấp $4,2 \%$ trong năm tài khóa 2006 đến mức cao $6,1 \%$ trong năm tài khóa 2010. Sự bất ổn này xảy ra là bởi số tiền phân bổ cho năm tiếp theo được xác định trước khi bắt đầu năm tài chính và trước khi biết giá trị thị trường vào cuối năm. Harvard lựa chọn tính toán theo phương pháp này là để cho phép các trường và các đơn vị trực thuộc có đủ thời gian để lập kế hoạch tài chính.

Việc sử dụng công thức xuất chi có nghĩa là tỷ lệ xuất chi hàng năm thường thấp hơn những năm có lợi tức đầu tư tương đổi cao và cao hơn những năm sau khi mà lợi nhuận đầu tư thấp. Điều chỉnh có thể được thực hiện trong những năm tiếp theo, với điều kiện duy trì và đảm bảo các mục tiêu thanh toán dài hạn để cân bằng sự ổn định ngân sách với việc duy trì sức mua của nguồn lực.

\section{Kỷ lục về giá trị gọi vốn và lý do thành công}

Chiến dịch gây quỹ của Đại học Harvard đã trở thành một cột mốc quan trọng khi số vốn kêu gọi được lên đển 9,6 triệu USD, trong khi mục tiêu ban đầu chỉ là 6,5 triệu USD. Việc gọi vốn thành công ngoài mong đợi đã nâng tổng giá trị quỹ tín thác Đại học Harvard lên 39,2 triệu USD, một con số chưa từng có của các quỹ từ thiện. Trong hơn năm năm, từ tháng 09 năm 2013 đến tháng 07 năm 2018, Harvard đã nhận được tài trợ từ hơn 150.000 tổ chức, cá nhân và hộ gia đình, bao gồm 46.000 nhà tài trợ mới.

Chiến dịch Harvard (The Harvard Campaign) thực sự là một thành công rất đáng học hỏi. Phân tích về nguyên nhân của số vốn kỷ lục mà Harvard huy động được, tác giả Heather Joslyn (2018) [13] đã chỉ ra các điểm sau đây:

\section{i) Sụ lãnh đạo nhiệt tình:}

Drew Gilpin Faust, người đảm nhận chức chủ tịch Công ty quản trị Harvard (HMC) từ năm 2007, là chìa khóa để kết nối với các nhà tài trợ. Điều này được Tamara Rogers, Phó chủ tịch về phát triển và kết nối cựu sinh viên nhận định trong phỏng vấn với báo Philanthropy. Ngay từ những ngày đầu tiên của nhiệm kỳ, bà Faust đã thường xuyên có những buổi gặp mặt, tiếp xúc với các trưởng khoa, chủ tịch các hội, nhóm sinh viên, học giả và cựu sinh viên để tạo lập các mối quan hệ. Cùng với đó, Rogers nhấn mạnh vai trò của người lãnh đạo qua việc thể hiện sự tin tưởng vào khả năng điều hành của Faust.

\section{ii) Nhu cầu truyền thông trong kỷ nguyên kỹ thuật số:}

Trước khi thực hiện chiến dịch gây quỹ, Harvard đã đưa ra những tuyên bố rất tích cực về quỹ tín thác. 6,5 triệu USD mục tiêu ban đầu là một con số không hề nhỏ, nhưng không vì vậy mà ngôi trường này bị tạo áp lực hay theo đuổi một cách gắt gao mục tiêu này. Thay vào đó, các con số được sử dụng một cách thông minh để tạo hiệu ứng truyền thông, thu hút sự chú ý của các công ty, tập đoàn lớn trên thế giới.

\section{iii) Một cấu trúc vù̀a bao hàm vù̀a phi tập trung:}

Đây là chiến dịch đầu tiên liên quan đến tất cả trường học, khoa, bộ môn chuyên ngành trong Harvard. Mỗi ngành đào tạo đều có một mục tiêu. Mỗi trưởng khoa đã tìm ra nhu cầu của từng phân môn cư thể, từ đó xác định các ưu tiên và nhà tài trợ tiềm năng. Những người đứng đầu các trường trực thuộc cũng đồng thời là thành viên của ủy ban điều hành chiến dịch và trong các nhóm hỗ trợ tự nguyện. Nhân sự thực hiện Chiến dịch Harvard được ví như một ma trận xuyên suốt toàn bộ. Khi mỗi trường trực thuộc đạt được mục tiêu đề ra cũng là khi Harvard thành công với chiến dịch gọi vốn của mình.

\section{iv) Đội ngũ nhân viên phát triển được đào tạo bài bản:}

Harvard đã cắt giảm nhân sự sau khi nguồn quỹ tín thác bị ảnh hưởng trong thời kỳ suy thoái tài chính vào năm 2007. Vào thời điểm chiến dịch gọi vốn được công bố rộng rãi tới công chúng, quy mô nhân sự trở về con số không. Thêm vào đó, các trường đại học đều thuê thêm nhân viên gây quỹ để thu hút những món quà 
hiến tặng trị giá 10 triệu USD trở lên nhằm mang lại lợi ích cho toàn bộ trường hoặc cho các dự án thuộc sự bảo hộ bởi các trường trực thuộc, chẳng hạn như dự án nghiên cứu tế bào gốc hay quỹ học bổng kinh tế học hành vi. Trong một thị trường việc làm đầy biến động, sự tiêu hao nhân lực luôn là một thách thức hiện hữu với các quỹ tài trợ. Những người đang làm tại Harvard có thể sẽ bị các tổ chức khác cướp đi bởi vì khi chiến dịch đã đạt được những kết quả nhất định, các nhân viên quỹ thường có xu hướng nhảy việc vì đã có thể ghi nhận thành tích trong bản lý lịch cho những lần xin việc tiếp theo. Vì vậy, giữ cho đội ngũ phát triển ổn định luôn là một thách thức đối với bất kỳ nhà quản trị quỹ tín thác nào. Hội đồng quản lý quỹ tín thác Harvard đã có những chiến lược sáng tạo khi nới lỏng các yêu cầu ứng tuyển để lấp đầy các vị trí trống. Họ chấp nhận tuyển dụng cả nhân sự của phòng tuyển dụng, tài chính - kế toán, hay tư vấn, hoặc từ các lĩnh vực khác. Harvard tin rằng điều này giúp đem lại nhiều lối tư duy mới. Thực tế đã chứng minh sự thành công của chiến lược này.

\section{v) Số lượng lớn các tình nguyện viên:}

Tình nguyện viên giữ vai trò quan trọng và họ đóng góp cho Chiến dịch Harvard ở nhiều cấp độ khác nhau. Hơn 40 ủy ban với hơn 1.400 tình nguyện viên đã giúp thúc đẩy các nỗ lực kêu gọi tài trợ. Tại tám trường trực thuộc, ủy ban chiến dịch có ít nhất một đồng chủ tịch không phải là cựu sinh viên của trường đó. Điều này giúp thúc đẩy sự quan tâm của các nhà tài trợ tới những lợi ích, giá trị chung của các trường trực thuộc. Hầu hết các khoản đóng góp có trị giá từ 10 triệu USD trở lên được chuyển giao để hỗ trợ nhiều hơn một trường học trực thuộc Đại học Harvard. 15\% nguồn vốn Harvard thu được không đến từ các cựu học sinh của trường.

\section{vi) Phong trào gây quỹ mạnh mẽ trên cấp độ quốc tế:}

Người dân từ 173 quốc gia đã quyên góp cho Chiến dịch Harvard, phản ánh tính toàn cầu của không chỉ ngôi trường danh tiếng này mà còn của chiến dịch gọi vốn tài trợ lớn nhất trong các tổ chức giáo dục. Trường đại học tìm kiếm các tình nguyện viên chiến dịch ở nhiều quốc gia và tổ chức các sự kiện Harvard của bạn cho các cựu sinh viên trên khắp nước Mỹ và trên thế giới, từ đó truyền đi thông điệp từ Chủ tịch quỹ, bà Faust. Các sự kiện được tổ chức không nhằm mục đích gây quỹ một cách lộ liễu mà để các cựu sinh viên ở xa cảm thấy được kết nối với trường và được thông báo về chiến dịch. Ngoài ra, Harvard cũng vận hành thành công các câu lạc bộ Harvard trên khắp thế giới để thực hiện các chương trình khác nhau. Đôi khi, dưới sự điều hành của bộ phận tuyển sinh, các câu lạc bộ sẽ nhờ cựu sinh viên phỏng vấn các sinh viên tiềm năng trong trường hợp họ không thể đến trụ sở chính của Harvard tại Massachusetts. Đội ngũ nhân viên chiến dịch cũng tích cực tìm kiếm lời khuyên của các nhà hảo tâm ở một số quốc gia nơi việc quyên tặng cho các cơ sở giáo dục còn khá mới mẻ để lan tỏa Chiến dịch Harvard đến nhiều người hơn.

\section{Công thức phân bổ quỹ tín thác trường đại học Harvard}

Khoản tín thác vẫn là nguồn thu lớn nhất hỗ trợ cho ngân sách của đại học Harvard. Trong năm tài khóa 2018, phân bổ tín thác cho vận hành chiếm 35\% tổng thu nhập của trường. Quỹ tín thác hỗ trợ gần như mọi khía cạnh hoạt động của Harvard. Hai loại quỹ lớn nhất bao gồm quỹ lương của các bộ, ban, khoa chuyên ngành, bao gồm lương cho giáo sư và các chương trình, dự án hỗ trợ nâng cao trình độ, đánh giá giáo sư; hỗ trợ tài chính cho sinh viên đại học, học bổng sau đại học, và các khoản trợ cấp cho cuộc sống và hoạt động của sinh viên. Harvard cũng hỗ trợ cho các chương trình học thuật, thư viện, bảo tàng nghệ thuật, cơ sở vật chất và nhiều hoạt động khác.

Ngay cả với nguồn hỗ trợ từ quỹ tín thác, gần hai phần ba chi phí hoạt động của Harvard $(5,0$ tỷ USD trong năm tài khóa 2018) phải dựa vào các nguồn thu khác, chẳng hạn như tài trợ nghiên cứu của liên bang và ngoài liên bang, học phí và lệ phí của sinh viên, và các khoản quyên tặng ngoài tín thác từ cựu sinh viên, phụ huynh, và những người cộng sự. 


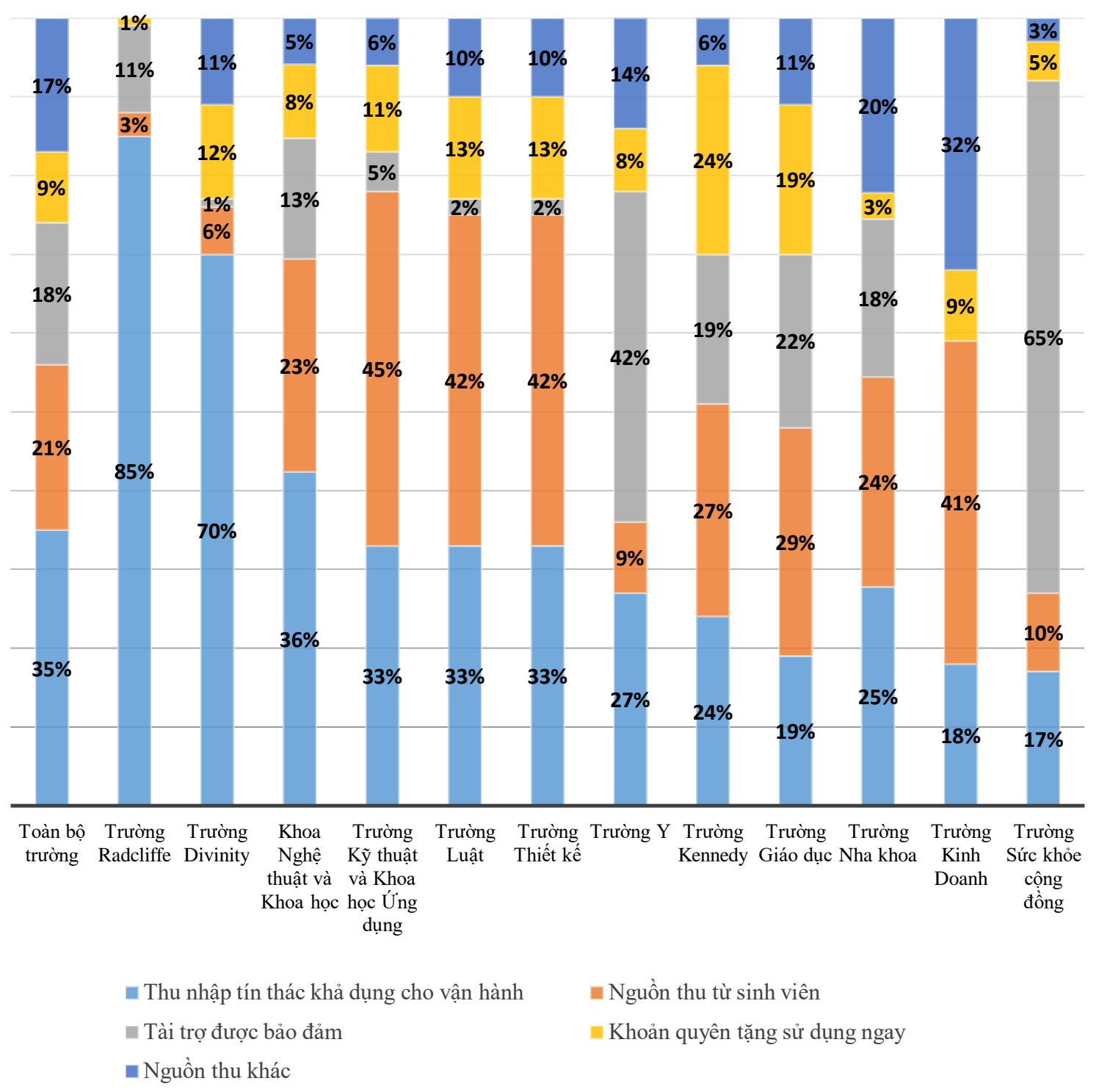

Hình 2. Cơ cấu nguồn thu tại Harvard và các đơn vị học thuật trực thuộc năm 2018

Nguồn: Báo cáo tài chính Đại học Harvard, 2018 [12]

Giống như bất kỳ đơn vị ủy thác có chức năng giám sát tài trợ nào khác với mục đích vừa duy trì dài lâu vừa tài trợ cho các hoạt động hiện tại, HMC gặp nhiều khó khăn để cân bằng hai thái cực:

i) Bảo vệ giá trị của tài sản trong dài hạn;

ii) Sử dụng ngân sách cho mục đích vận hành hiện tại và rút ngắn khoảng thời gian cần thiết để hoàn thành công việc.
Một quy tắc đơn giản để giữ nguyên giá trị tài sản có thể là trong mỗi năm tài khóa, chỉ 5\% giá trị (kể từ ngày định giá trước hoặc định giá dự kiến trong tương lai) sẽ được phân bổ. Một quy tắc cố định như vậy sẽ rất nhạy cảm với các thị trường biến động. Mức phân phối sẽ tăng vọt khi thị trường đầu tư tăng cao, giúp cho công việc của các cán bộ tài chính trở nên đơn giản hơn. Điển hình là khi quỹ tín thác Harvard đạt 
biên lợi nhuận 32,2\% trong năm 2000 hoặc $23 \%$ trong năm 2017. Tuy nhiên, cố định mức phân bổ có thể dẫn đến sự trì hoãn có thể vô cùng nghiêm trọng, bao gồm các trường hợp sa thải khẩn cấp và những gián đoạn không mong muốn khác, hoặc trong những năm đầu tư bất lợi hoặc thất bại thảm hại, hoặc trong các tình huống thua lỗ. Dù là một quỹ tín thác thành công nhưng Harvard cũng đã phải trải qua mức lợi nhuận $2,7 \%$ năm 2001 , và lên đến $-27,3 \%$ vào năm 2009.

Quy tắc này có hiệu lực tự động, điều cốt lõi là bảo vệ giá trị tiềm năng của quỹ (và phục hồi giá trị trong tương lai) sau khi có kết quả đầu tư bất lợi. Có thể dễ dàng để thấy các tổ chức kêu gọi tài trợ vận hành như thế nào, nhưng khó khẳng định rẳng một khoản phân bổ cố định là chiến lược tốt nhất cho một thực thể hoạt động như một trường đại học, với chi phí xây dựng cố định và rất nhiều người trong biên chế phụ thuộc vào nguồn thu của quỹ tín thác.

Một quy tắc đơn giản để dự đoán ngân sách là tăng dần phân bổ tín thác một số phần trăm mỗi năm: một tỷ lệ cố định hoặc một số đại diện cho lạm phát (trong trường hợp của Harvard, trường đã sử dụng Chỉ số giá giáo dục đại học hay HEPI, là đại diện thông thường). Ý tưởng của việc làm này là thiết lập một lộ trình cho ngân sách ngắn hạn và nhiều năm, đồng thời tạo lập kế hoạch tài chính liên quan, trong khi tính toán cả một số yếu tố lạm phát để duy trì sức mua thực sự gắn với các khoản tiền được giải ngân. Để đối phó với các biến động giá trị của các tài sản tài chính cơ bản, phương pháp điển hình là lấy mức phân bổ có thể chấp nhận được trong bất kỳ năm nào đối với một nhóm thanh toán: một tỷ lệ giá trị thị trường của tài sản, có thể là $4 \%$ đến $6,25 \%$, được sử dụng vì mục đích chống đầu cơ khi lợi nhuận thị trường rất cao trong một thời gian dài, hoặc rủi ro làm cạn kiệt tiền gốc nếu điều ngược lại xảy ra. Nguyên tắc này cũng được Đại học Princeton, nơi có khoãn quỹ tín thác trên mỗi sinh viên cao nhất, áp dụng.

Đối mặt với thị trường tài chính bất ổn, để duy trì sức mua dài hạn và đáp ứng nhu cầu vận hành, $\mathrm{HMC}$ thường tìm kiếm một công thức cân bằng: một nguồn ngân sách liên tục (liên tục để phân bổ ở hiện tại và phân phối gần) và cân nhắc giá trị thị trường theo một cách nào đó. Báo cáo tài chính hàng năm gần đây nhất của Đại học Harvard nhận định rằng: "Các chính sách phân phối quỹ tín thác đại học Harvard được thiết kế để giữ vững giá trị quỹ theo giá trị thực (sau lạm phát) và tạo ra một dòng thu nhập khả dụng có thể dự đoán được. Vào mỗi mùa thu, công ty sẽ phê duyệt phân bổ tín thác cho năm tài chính tiếp theo. Phân phối quỹ dựa trên chỉ dẫn giả định từ một công thức nhằm cung cấp sự ổn định ngân sách bằng cách làm giảm tác động của các khoản lãi và lô̂ đầu tư hàng năm. Yếu tố đầu vào của công thức phản ánh kỳ vọng về lợi nhuận dài hạn và tỷ lệ lạm phát."

Trong thực tế, Harvard chỉ định trọng số $70 \%$ cho sự phân bổ của năm tài chính trước đó và $30 \%$ cho giá trị thị trường hiện tại/ giá trị thị trường dự kiến của khoản tài trợ. Trong bất kỳ năm nào, công thức này cũng tạo ra sự nâng đỡ cho các hoạt động của trường nhờ sự thay đồi lớn về giá trị tín thác. Trong khoảng thời gian vài năm, nếu lợi nhuận đầu tư có xu hướng tăng hoặc giảm rất mạnh, hiệu ứng này sẽ trở nên không rõ ràng ở các lần lặp lại liên tiếp của phần trọng số phân phối trong công thức.

Trên hết, điều quan trọng theo quan điểm của Công ty quản lý quỹ là khoản phân bổ trên mỗi cổ phần tương đương của tài trợ mỗi năm. Tuy thế, có vô số yếu tố ảnh hưởng đển giá trị tín thác như: tỷ lệ hoàn vốn đầu tư; các quỹ được phân bổ cho vận hành; quỹ bổ sung được phân phối cho các mục đích một lần (còn gọi là - rút vốn); quỹ tạm thời được hoàn trả để đầu tư cùng với tài sản tín thác (tái cấp vốn); và quà quyên tặng nhận được.

Mặc dù giá trị tổng thay đổi từ năm này sang năm khác, vào cuối năm, việc rút vốn đã cân bằng 200 triệu USD hoặc hơn thế. Ngoài ra, Chiến dịch Harvard cũng giúp tạo ra một dòng tiền vô cùng lớn hàng năm vì mục đích hồ trợ tài chính.

Để hiểu rõ hơn về nguyên tắc phân bổ quỹ tín thác của Harvard, tác giả tập trung vào một đơn vị tài trợ được đơn giản hóa và tiếp tục đơn giản hóa số học bằng cách giả định mức phân bổ 
mỗi năm là 5 USD trên một đơn vị tín thác trị giá 100 USD.

Trong một năm lợi nhuận đầu tư lớn hơn khoản phân bồ:

Mới đầu, một đơn vị tín thác trị giá 100 USD. Phân bổ trong năm là $5 \%$ (tức 5 USD) và HMC báo cáo lợi nhuận đầu tư là $10 \%$, mang lại giá trị thị trường là 104,50 USD (100 USD trừ 5 USD bằng 95 USD, lợi nhuận đầu tư $10 \%$ có giá trị 1,1 lần 95 USD bằng 104,50 USD).

\section{Bước 1. Phân bổ:}

Tổng giá trị hiện tại $(\$ 5,00)$, được điều chỉnh theo lạm phát HEPI giả định là $3 \%$ : $(\$ 5,00 \mathrm{x}$ $1,03)=\$ 5,15$; số tiền đó sau đó được áp trọng số $70 \%$ (nhân 0,70$)$, mang lại một khoản tiền là 3,61 USD.

\section{Bước 2. Giá trị thị trường:}

Dự kiến giá trị thị trường ban đầu là $\$ 104,50$ trong một năm, sử dụng giả định lợi nhuận dài hạn là $8 \%$ và nằm trong phần phân bổ trong giai đoạn hiện tại $(\$ 104,50-\$ 5,50=\$ 99,50)$ nhân 1,08 tạo ra giá trị $\$ 107,46$; nhân giá trị thị trường dự kiến đó với tỷ lệ phân phối mục tiêu $(5 \%$ hoặc $0,05)$ bằng $\$ 5,37$; số tiền đó sau đó được tính trọng số ở mức 30\% (lần 0,30 ), mang lại số tiền là $\$ 1,61$.

\section{Bước 3.}

Kết hợp hai khoản tiền $(\$ 3,61$ cộng với $\$ 1,61)$, thu được kết quả là $\$ 5,22$.

\section{Bước 4.}

Chia kết quả cho phân phối trước (5,22 USD chia cho 5,00 USD), tạo ra mức gia tăng 4\% trong tổng số tiền trên mỗi đơn vị tài trợ được phân chia cho các đơn vị trực thuộc, trong năm tài chính tiếp theo.

Trong ví dụ tích cực này, vì giá trị tài trợ tăng 5\% sau khi phân bổ cho hoạt động, được tạo ra bởi lợi tức đầu tư $10 \%$ trên tài sản, dòng tiền của ngân sách hoạt động từ nguồn đó sẽ tăng $4 \%$ : kết quả khả quan mang lại sự an tâm rằng khoản hoàn trả sau đầu tư sẽ không có giá trị thấp đi trong tương lai.

Ngược lại, trong một năm lợi nhuận đầu tư kém hiệu quả hoặc thua lỗ, khi giá trị của tài sản giảm, các công thức số học sẽ điều chỉnh như sau:

Khi bắt đầu, một đơn vị tài trợ trị giá 100 USD. Phân phối trong năm là $5 \%$ (5 USD) và HMC báo cáo lợi tức đầu tư là $-5 \%$, khiến giá trị thị trường giảm còn 90,25 USD (100 USD trừ 5 USD bằng 95 USD, kêt quả đầu tư - $5 \%$ âm tính với giá trị 0,95 lần 95 USD bằng $\$ 90,25$ ).

\section{Bước 1. Phân phối:}

Tổng tiền kỳ trước $(\$ 5,00)$, được điều chỉnh theo lạm phát HEPI giả định là 3 phần trăm $(\$ 5,00 \times 1,03)$ bằng $\$ 5,15$; số tiền đó sau đó được gắn trọng số $70 \%$ (gấp 0,70 ), tạo ra một khoản tiền là 3,61 USD.

\section{Bước 2. Giá trị thị trường:}

Dự kiến giá trị thị trường khởi điểm là 90,25 USD một năm, sử dụng giả định lợi nhuận dài hạn là $8 \%$ và chiếm trong phân bổ của giai đoạn hiện tại $(90,25$ USD trừ 5,00 USD bằng 85,25 USD) x 1,08, được kết quả là 92,07 USD. Nhân giá trị thị trường dự kiến đó với tỷ lệ phân phối mục tiêu $(5 \%$ hoặc 0,05$)$ bằng $\$ 4,60$; số tiền đó sau đó được tính trọng sổ ở mức 30\% (lần 0,30 ), mang lại số tiền là $\$ 1,38$.

\section{Bước 3.}

Kết hợp hai khoản tiền $(\$ 3,61$ cộng $\$ 1,38)$, thu được kết quả là $\$ 4,99$.

\section{Bước 4.}

Chia kết quả cho phân phối trước (4,99 USD chia cho 5,00 USD), ta được mức thay đổi xấp xỉ $0 \%$ trong tổng số tiền trên mỗi đơn vị tài trợ được phân phối cho các đơn vị trực thuộc, trong năm tài chính tiếp theo.

Trong ví dụ này, vì giá trị tài trợ giảm $10 \%$ sau khi phân bổ cho vận hành, và được tạo ra từ sự ngang bằng lợi nhuận đầu tư trên tài sản âm và kết quả của quyên tặng cho các trường, dòng tiền ngân sách hoạt động từ nguồn đó sẽ không thể tăng trong giai đoạn tiếp theo: một kết quả được cân đối giúp duy trì ngân sách ngắn hạn khỏi tỷ suất lợi nhuận bất lợi ở hiện tại.

Mô hình 2: Quỹ tín thác trường đại học dưới sự quản lý của nhà trường 
Ở mô hình này công ty quản lý quỹ là một văn phòng trực thuộc ban quản lý trường đại học. Văn phòng này giữ vai trò thiết kế danh mục đầu tư và thực hiện đầu tư các loại tài sản, tài sản tài chính của trường để hỗ trợ những mục tiêu dài hạn. Công ty quản lý quỹ được tích hợp chặt chẽ vào các hoạt động thường nhật của trường đại học như học tập, giảng dạy, nghiên cứu [14].

Điểm mạnh của mô hình này là các nhà quản lý quỹ nắm bắt được hoạt động vận hành của trường đại học để từ đó đưa ra các phương án phân bổ hợp lý. Ngoài ra, đơn vị này tạo ra các cơ hội làm việc chuyên nghiệp cho các sinh viên, cựu sinh viên của trường vốn đã theo học và yêu thích đầu tư tài chính. Việc tận dụng nguồn nhân lực hiện có trong đội ngũ giảng viên, nhân viên và sinh viên ngay tại trường học đồng thời làm giảm tối đa chi phí tiền lương cho nhân viên.

Tuy nhiên, sự can thiệp quá sâu của các hoạt động hàn lâm có thể khiến các quyết định đầu tư bị trì hoãn, làm giảm tính hiệu quả của quỹ tín thác [9]. Điển hình của mô hình thứ hai này là Quỹ tín thác Đại học Stanford được quản lý bởi Công ty Quản lý Stanford (SMC), một bộ phận trong trường đại học được giám sát bởi Ban giám đốc do Hội đồng Ủy thác trường Đại học bổ nhiệm.

Nhóm đầu tư theo dõi sát sao và liên tục các nhóm tài sản để điều chỉnh danh mục đầu tư của đại học Stanford và xác định các cơ hội đầu tư mới, giúp tạo ra nguồn lợi nhuận tối ưu. Ngoài việc công việc chính là quản trị các danh mục đầu tư, báo cáo kết quả đầu tư cho Ban giám đốc để Hội đồng Ủy thác trường đại học thực hiện phân bổ một cách hợp lý, SMC còn là môi trường chuyên nghiệp để các sinh viên đại học và sau đại học học hỏi và thực hành đầu tư quỹ.

\section{Mục tiêu của quỹ tín thác Đại học Stanford}

Chiến lược đầu tư của SMC được thiết kế để hỗ trợ vật chất cho các hoạt động thường niên của trường, đồng thời, duy trì sức mua của quỹ tín thác đề các thế hệ sinh viên và nghiên cứu sinh trong tương lai vẫn tiếp tục được hưởng lợi.

Mục tiêu sứ mệnh kép của SMC là đưa ra một chương trình đầu tư theo định hướng vốn để tạo ra dòng lợi nhuận thực tế dài hạn đủ cao, và đa dạng hóa tối ưu danh mục đầu tư để giảm bớt biến động hàng năm và giảm thiểu rủi ro mất khoản tiền gốc. Hiểu rõ tôn chỉ của Đại học Stanford, SMC áp dụng các thang đánh giá nghiêm ngặt về rủi ro và lợi để hình thành một mô hình phân bổ tài sản tối ưu giúp đem lại lợi nhuận tương xứng theo thời gian. Trong mối loại tài sản, SMC chọn các đối tác bên ngoài, chuyên gia để thực hiện các quyết định ở cấp độ bảo mật và thúc đẩy lợi nhuận từ hoạt động.

Quỹ hợp nhất bao gồm cổ phiếu công trong và ngoài nước, bất động sản, tài nguyên thiên nhiên và vốn cổ phần tư nhân. Trong khi danh mục đầu tư chủ yếu là vốn chủ sở hữu, các chiến lược hoàn vốn tuyệt đối có tương quan thấp để mở rộng phần lớn thị trường, góp phần đáng kể vào sự đa dạng hóa danh mục đầu tư. Tuân thủ những mục tiêu dài hạn của trường đại học, chương trình đầu tư của SMC được thiết kế để chấp nhận một mức độ thanh khoản tương đối để gia tăng lợi nhuận. Một phần nhỏ của kho vốn hợp nhất được đầu tư dưới dạng thu nhập cố định chất lượng cao và tiền mặt vì mục đích thanh khoản.

\section{Chính sách đầu tư của quỹ tín thác Đại học Stanford}

Quỹ hợp nhất là kết quả của nhiều chiến lược định hướng giá trị vốn cổ phần, bao gồm cổ phần công trong và ngoài nước, bất động sản, tài nguyên thiên nhiên và vốn cổ phần tư nhân. Trong khi vốn chủ sở hữu chiếm phần lớn danh mục đầu tư, các chiến lược hoàn vốn tuyệt đối có tương quan thấp với các thị trường lớn góp phần tạo sự đa dạng hóa đầu tư. Một phần nhỏ trong giá trị quỹ hợp nhất được đầu tư với mức độ rủi ro thấp, tạo thu nhập cố định chất lượng cao và tiền mặt cho mục đích thanh khoản.

Dựa trên mô hình giá trị trung bình và phương sai trung bình, cách thức phân bổ tài sản hiện tại dự kiến sẽ tạo ra lợi nhuận số học hàng năm là 7.6\% (sau khi đã điều chỉnh tác động trong lạm phát giáo dục bậc cao và các loại phí, lệ phí) với mức biến động hàng năm là $13,8 \%$, tương ứng với tỷ lệ hoàn trả thực tế dự kiến 6,6\%. Để duy trì các đặc điểm lợi nhuận rủi ro 
mong muốn khi điều kiện thị trường thay đổi, SMC thắt chặt việc quản lý mức tiếp xúc của lớp tài sản và thường xuyên cân bằng lại danh mục đầu tư để phục vụ hợp lý nhất các mục tiêu chính sách của trường. Trong khi các mục tiêu chính sách chỉ được xem xét lại một lần mỗi năm, những thay đổi về mức độ giá trị của các loại tài sản xảy ra thường xuyên hơn khi các cơ hội thị trường đến. Dưới sự điều hành của nhà trường, SMC phải cân đối giữa những cơ hội đầu tư có

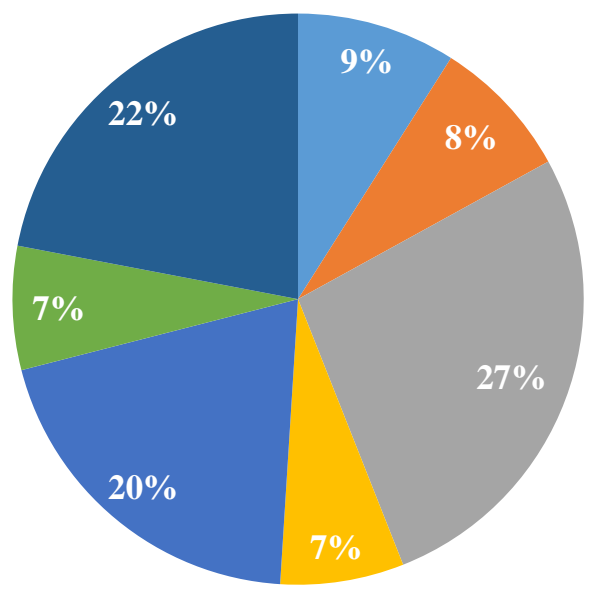

rủi ro cao nhưng đem lại lợi nhuận lớn và những khoản đầu tư mang lại lợi ích về lâu dài với mức độ rủi ro thấp hơn. Nguyên tắc này thúc đẩy một cách tiếp cận giá trị nhạy cảm, phù hợp với chiến lược trọng tâm dài hạn của Stanford. Mục tiêu tối quan trọng vẫn là duy trì và phát triển sứ mệnh của Đại học Stanford, thể hiện tư duy ủy thác rõ ràng và xem xét thực hiện phúc lợi cho con người và môi trường.

Hình 3. Cơ cấu phân bổ tài sản trong quỹ tín thác đại học Stanford năm 2018 (đơn vị: \%)

Nguồn: Báo cáo tài chính Đại học Stanford, 2018 [15]

\section{4. Đánh giá khả năng áp dụng mô hình quỹ tín thác trường đại học Hoa Kỳ tại các trường đại học Việt Nam}

Nghiên cứu mô hình quỹ tín thác của Hoa Kỳ, nhóm nghiên cứu đã nhận thấy những điều kiện thuận lợi để áp dụng mô hình này tại các trường đại học Việt Nam.

\section{i) Truyền thống quyên góp, hiến tặng của người dân Việt Nam}

Đóng góp, quyên tặng hay từ thiện ở Việt Nam đã tồn tại từ lâu đời. Đóng góp của các nhà hảo tâm ở các vùng nông thôn cũng như các đền chùa trên khắp cả nước đã được ghi nhận trong lịch sử. Trong một đất nước nông nghiệp và xã hội mang tính cộng đồng, nhiều người đã đóng góp cho sự tồn tại của cộng đồng và hỗ trợ những cá nhân kém may mắn hơn mình thông qua các tổ chức tại thôn xã, đền chùa, nhà thờ và tổ chức dòng họ. Trong những thập kỷ gần đây, đóng góp từ thiện ở Việt Nam thường được huy động qua các kênh chính thức hoặc các tổ chức chính trị xã hội như Mặt trận Tổ quốc, Hội Phụ nữ và Hội Nông dân. Mặc dù nguồn đóng góp chủ yếu vẫn đến từ các cá nhân, những đóng góp từ các doanh nghiệp đang ngày càng tăng nhờ các thành tựu kinh tế đạt được trong thập kỷ qua [16].

Theo nghiên cứu của Trung tâm Nghiên cứu Châu Á - Thái Bình Dương Hà Nội (2011) [17], nhu cầu quyên tặng của người dân Việt Nam cả ở thành thị lẫn nông thôn là rất lớn. Đa số hộ gia đình đều bày tỏ mong muốn làm việc thiện $(73 \%$ số hộ ở nông thôn và $51 \%$ số hộ ở thành phố) và quan tâm đển hoạt động từ thiện $(87 \%$ ở nông thôn và $59 \%$ ở thành phố). 
Kết quả khảo sát cũng chỉ ra rằng, mức độ đóng góp cho các hoạt động từ thiện của một hộ gia đình trong mẫu khảo sát hoàn toàn không nhỏ, giá trị quy đổi thành tiền cho các hoạt động quyên tặng qua những kênh khác nhau lên đến 800.000 $\mathrm{VNĐ/hộ/năm} \mathrm{(trong} \mathrm{đó} 178.000 \mathrm{VNĐ}$ qua các kênh chính thức và 627.000 VNĐ qua các kênh phi chính thức). Mặc dù mặt bằng kinh tế khác nhau, năng lực đóng góp từ thiện ở khu vực nông thôn và thành thị không có sự chênh lệch lớn. Kết quả cho thấy, trong 12 tháng trước thời điểm khảo sát, bình quân mỗi hộ gia đình ở thành phố đóng góp cho các kênh tiếp nhận chính thức 285.000 VNĐ, cho các kênh phi chính thức là trên 680.000 VNĐ. Trong khi đó, ở nông thôn, mỗi hộ gia đình bình quân đóng góp chưa đầy $60.000 \mathrm{VNĐ}$ cho các kênh từ thiện chính thức nhưng ủng hộ đến 574.000 VNĐ qua các kênh phi chính thức. Số liệu trên phản ánh sự khác biệt về các kênh đóng góp từ thiện giữa nông thôn và thành thị.

Nghiên cứu cũng chỉ ra tiềm năng làm từ thiện trong nhân dân còn rất lớn. Hơn $74 \%$ hộ gia đình ở thành thị và $89 \%$ hộ nông thôn cho biết sự đóng góp từ thiện hiện nay là ít hoặc chỉ ở mức độ vừa phải so với khả năng của họ. Thậm chí $94 \%$ hộ nông thôn và $89 \%$ hộ thành phố còn có ý kiến rằng mức độ đóng góp đó không có ảnh hưởng hoặc ảnh hưởng không đáng kể đến kinh tế hộ gia đình.

\section{ii) Sự tham gia tích cực của khối doanh nghiệp tư nhân và các tổ chức xã hội trong sự nghiệp giáo dục}

Ông Nguyễn Ngọc Lâm, Chủ tịch Trung tâm nghiên cứu, quản lý và phát triển bền vững, nhận định: "Nhiều tổ chức xã hội (TCXH) đã tham gia mạnh mẽ vào chủ trương xã hội hóa các vấn đề về y tế, giáo dục, thể dục, thể thao, từ thiện, nhân đạo... Họ đã triển khai nhiều mô hình mới, từ triển khai sản xuất, tăng thu nhập cho người nghèo, tham gia vào thị trường lao động, giải quyết vấn đề lao động”. Qua đó có thể thấy rằng, TCXH có một vai trò rất quan trọng vì nó tập hợp đông đảo lực lượng xã hội tham gia góp phần xây dựng kinh tế - xã hội thông qua những hoạt động như: là người đại diện cho các đối tượng cần sự trợ giúp; có thể hỗ trợ về mặt kỹ thuật; cung cấp thông tin; tiến hành các hoạt động công tác xã hội hướng vào việc thực hiện an sinh xã hội, phúc lợi xã hội,...

Kết quả khảo sát 516 doanh nghiệp tư nhân Việt Nam, Đặng Hoàng Giang và Phạm Minh Trí (2013) [18] chỉ ra rằng, có đến gần $80 \%$ công ty có thực hiện các hoạt động quyên tặng, từ thiện trong vòng 12 tháng gần đây. Tổng giá trị tiền mặt đóng góp nhân đạo, từ thiện của 396 công ty trên là 113 tỷ đồng, giá trị hiện vật ước tính 14 tỷ đồng. Ba lĩnh vực mà các doanh nghiệp tích cực làm ủng hộ, quyên góp tiền và hiện vật là: giúp đỡ những người có hoàn cảnh khó khăn như mẹ Việt Nam anh hùng, cựu chiến binh hoặc các trung tâm trẻ mồ côi (chiếm $73 \%$ ); cứu trợ thiên tai $(51 \%)$ và giảm nghèo $(47 \%)$. Giáo dục cũng là một mục đích từ thiện tương đối phổ biến khi có khoảng $27 \%$ doanh nghiệp tham gia khảo sát quyên tặng vì mục đích này.

Điều này chứng tỏ các doanh nghiệp Việt Nam ngày càng quan tâm hơn đến môi trường và chất lượng giáo dục, bởi đây chính là nơi đào tạo lực lượng lao động chủ yếu cho các công ty.

\section{iii) Sự ổn định của thị trường tài chính}

Sự thành công của quỹ tín thác trường đại học Hoa Kỳ đến từ nhiều yếu tố, trong đó có việc đầu tư tài chính hiệu quả. Khi các thể chế giáo dục còn mới lạ với các hoạt động đầu tư, một nền tài chính ổn định góp phần không hề nhỏ trong quá trình tạo lợi nhuận của các khoản đầu tư từ quỹ tín thác.

Theo Báo cáo tóm tắt tổng quan thị trường tài chính năm 2018 [19] của Ủy ban giám sát tài chính quốc gia, bối cảnh kinh tế vĩ mô trong nước ta năm 2018 hết sức khả quan:

Tăng trưởng kinh tế năm 2018 đạt tốc độ tăng trưởng cao nhất 10 năm nhờ vào động lực chính là ngành công nghiệp chế biến chế tạo và ngành dịch vụ; nông, lâm thủy sản tăng trưởng tốt. Năm 2018, kinh tế Việt Nam ước tăng 6,97\%, đạt mức tăng cao nhất kể từ năm 2011. Trong đó, ngành công nghiệp chế biến chế tạo đóng góp khoảng 2,5 điểm $\%$ vào tăng trưởng; ngành dịch vụ đóng góp khoảng 2,75 điểm $\%$ vào tăng trưởng. Tổng cầu của nền kinh tế duy trì mức tăng khá, xuất khẩu và tiêu dùng tăng cao hơn cùng kỳ. 


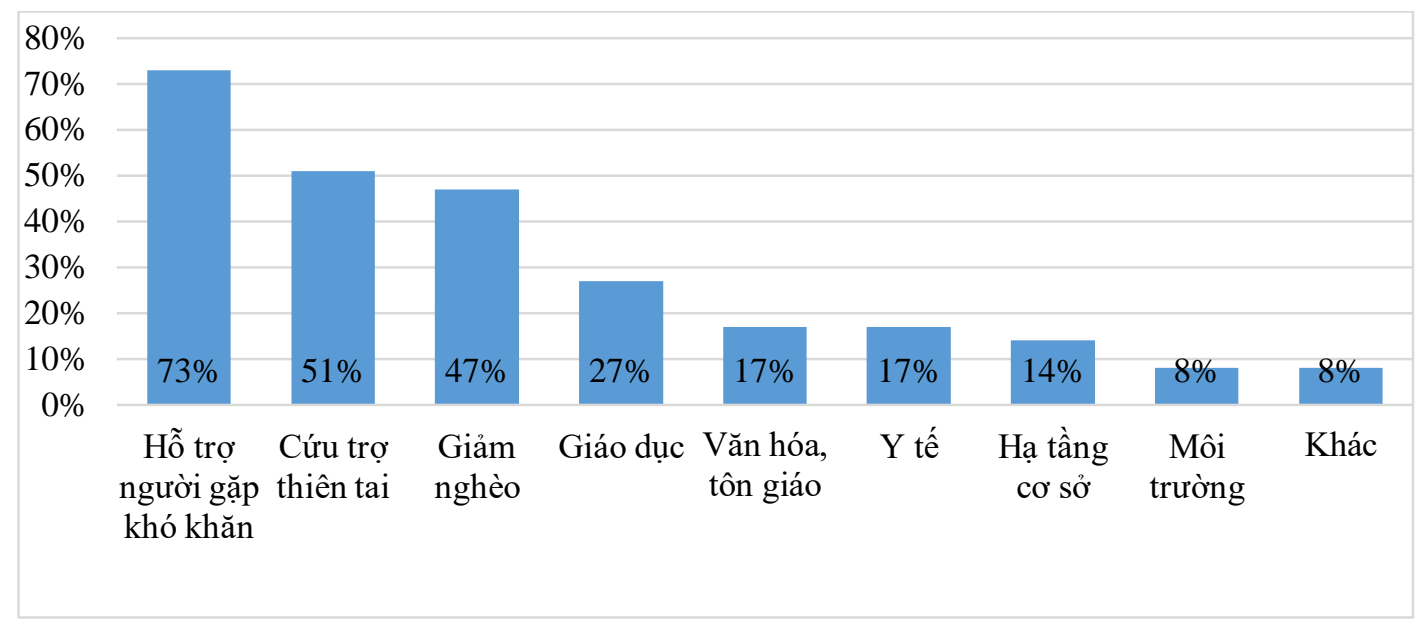

Hình 4. Các lĩnh vực nhận được đóng góp nhân đạo, từ thiện của doanh nghiệp Việt Nam

Nguồn: Đặng Hoàng Giang, Phạm Minh Trí, 2013[18]

Lạm phát bình quân cả năm ước khoảng 3,6\%. Lạm phát cơ bản bình quân tăng dưới $1,5 \%$ so với cùng kỳ. Nhân tố tác động chủ yếu đến lạm phát năm 2018 là thực phẩm và xăng dầu: giá thực phẩm tăng $6,67 \%$ so với đầu năm (đóng góp 1,51 điểm\%); nhóm giao thông tăng $7,3 \%$ so với đầu năm (đóng góp 0,68 điểm\%).

Cán cân thanh toán tổng thể thặng dư ở mức cao nhờ: i) Cán cân thương mại dự báo xuất siêu ở mức cao hơn năm 2017; ii) Cán cân tài chính tiếp tục thặng dư nhờ giải ngân FDI tiếp tục đạt khá, dòng vốn đầu tư gián tiếp đạt xấp xỉ 2 tỷ USD, kiều hối tăng trưởng trên $10 \%$; iii) Khoản mục lỗi và sai sót giảm mạnh so với năm 2017. Nhờ đó, ngân hàng nhà nước đã bổ sung được dự trữ ngoại hối lên mức cao kỷ lục (đạt khoảng 12 tuần nhập khẩu).

Cân đối ngân sách nhà nước đảm bảo tiến độ do thu ngân sách nhà nước đạt khá trong khi chi ngân sách nhà nước được kiểm soát, cơ cấu thu - chi cải thiện tích cực, nợ công/GDP có xu hướng giảm dần trong các năm gần đây. Tỷ lệ nợ công/GDP năm 2018 giảm và dự kiến đạt $61,4 \%$ (năm 2017: 62,6\%; năm 2016: 63,6\%)do tăng trưởng kinh tế khả 3 quan. Bên cạnh đó, nợ nước ngoài của quốc gia/GDP tăng từ $48,9 \%$ năm 2017 lên 49,7\% năm.
Cùng với những kết quả đáng khích lệ trong năm 2018, triển vọng kinh tế Việt Nam 2019 cũng ở mức cao:

Tăng trưởng GDP năm 2019 được dự báo có khả năng đạt $7 \%$. Phân rã tăng trưởng cho thấy, thành phần xu thế đã liên tục cải thiện trong những năm qua và được dự báo tiếp tục trong năm 2019. Ngoài ra, kinh tế Việt Nam có thể được hỗ trợ bởi các yếu tố quốc tế: i) hưởng lợi từ xu hướng dịch chuyển sản xuất do tác động của chiến tranh thương mại và ii) triển vọng từ các hiệp định mới như CPTPP và các Hiệp định thương mại tự do kiểu mới khác.

Lạm phát năm 2019 có thể chịu tác động từ yếu tổ giá thực phẩm và chi phí nguyên vật liệu dùng cho sản xuất tăng trong thời gian qua.Tuy nhiên, áp lực khiến CPI tăng mạnh là không nhiều do giá hàng hóa thế giới dự báo chỉ tăng nhẹ. Tính toán cho thấy, nếu chưa tính đến điều chỉnh giá dịch vụ công, CPI bình quân năm 2019 có thể dưới mức $3,6 \%$.

Tuy nhiên, đây là mô hình mới, vì vậy sẽ gặp một số khó khăn khi triển khai tại các trường đại học Việt Nam, có thể kể đến dưới đây:

\section{iv) Quan niệm hạn hẹp về mục đích của việc đóng góp, quyên tặng}

Theo một nghiên cứu được tiến hành năm 2015 của Viện Nghiên cứu Kinh tế, xã hội và 
môi trường, đa số người được hỏi hiểu về hoạt động từ thiện theo nghĩa hẹp, hay là "lá lành đùm lá rách”. Các hình thức đóng góp từ thiện khác, như đóng góp từ thiện để xây dựng các công trình công cộng hay hiến máu nhân đạo, cũng đôi khi được nhắc tới, nhưng chúng không phải là cách hiểu về từ thiện mà đa số người tham gia phỏng vấn sâu chia sẻ. Điều đáng nói là, trong các cuộc phỏng vấn, các hoạt động mang tính "phát triển" như bảo vệ quyền con người, khuyến học, chống tham nhũng hoặc bảo vệ môi trường rất ít khi được nhắc đến.

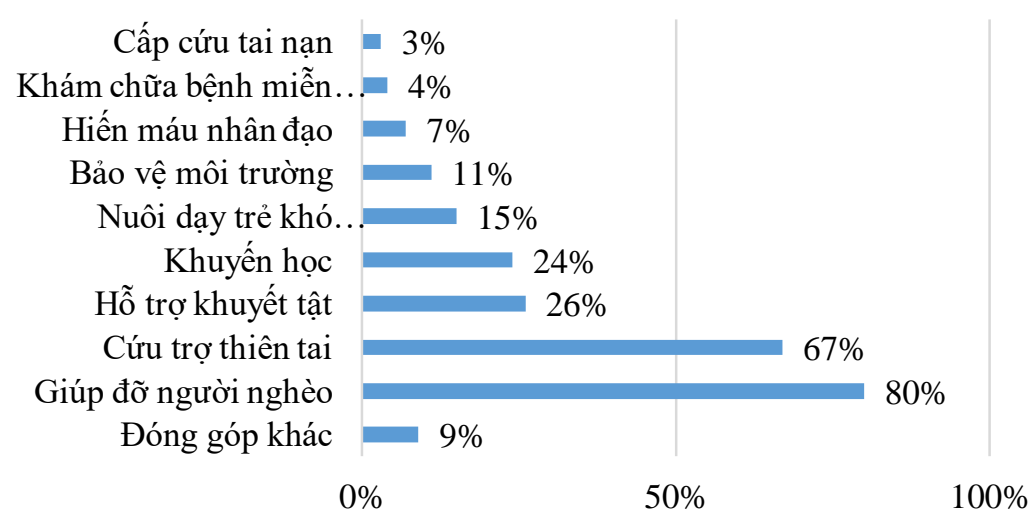

Hình 5. Mức độ phổ biến của các mục đích đóng góp, quyên tặng

Nguồn: Viện Nghiên cứu Kinh tế, xã hội và môi trường, 2015 [20]

Do quan niệm về từ thiện và lĩnh vực huy động từ thiện của chính quyền nên đa số người dân đóng góp cho các hoạt động giúp đỡ người nghèo và cứu trợ thiên tai. Điều này khiến cho các trường học hay các cơ sở giáo dục không phải là lựa chọn phổ biến khi các cá nhân muốn thực hiện hành động đóng góp, quyên tặng. Cũng theo kết quả khảo sát của Viện Nghiên cứu Kinh tế, xã hội và môi trường, trong tổng số 1137 người được hỏi, chỉ có khoảng 89 người lựa chọn hỗ trợ tài chính cho các trường học.

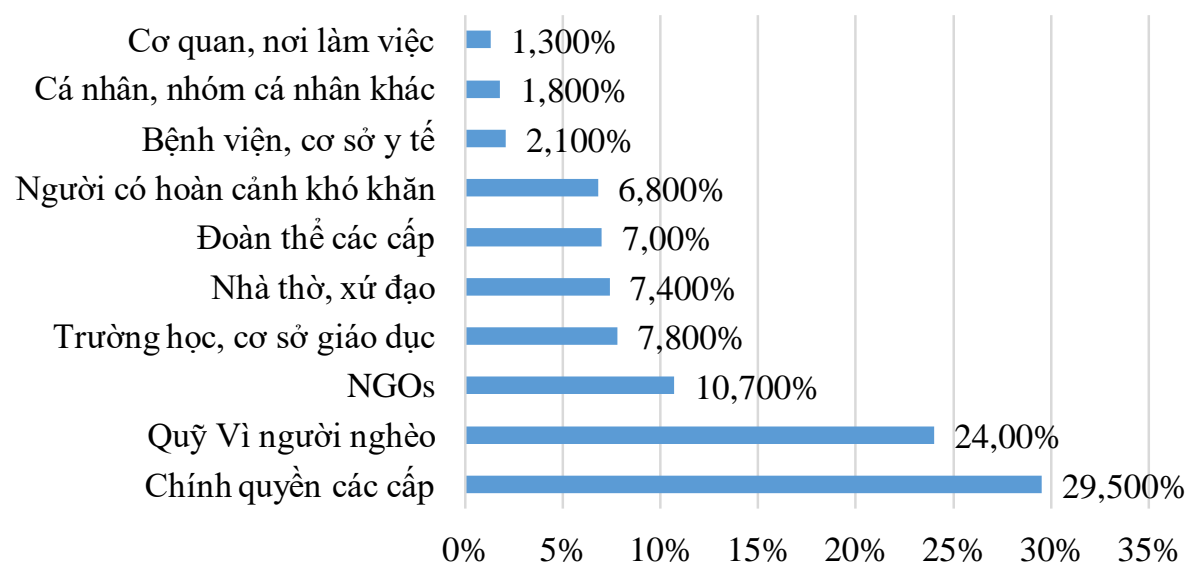

Hình 6. Mức độ phổ biến của các kênh nhận đóng góp từ thiện của người dân

Nguồn: Viện Nghiên cứu Kinh tế, xã hội và môi trường, 2015 [20] 


\section{v) Sự thiếu hiểu biết về quỹ tín thác trường đại học}

Để đánh giá mức độ nhận thức về quỹ tín thác trường đại học, người viết đã thực hiện một khảo sát với các sinh viên và cựu sinh viên của một số trường đại học trên địa bàn Hà Nội.

Trong số những người được hỏi, hơn $54 \%$ chưa từng biết đến quỹ tín thác. Điều này chứng tỏ, khái niệm về một quỹ tài chính phục vụ cho mục đích giáo dục còn rất mới mẻ với người Việt Nam. Vì chưa hiểu rõ vấn đề nên mọi người còn rất nhiều lo ngại khi được hỏi về mức độ khả thi của việc áp dụng quỹ tín thác trường đại học cho các cơ sở giáo dục bậc cao tại Việt Nam. Không có ai khẳng định chắc chắn mô hình này sẽ thành công khi được đưa vào các trường đại học. Hơn $6 \%$ số người được hỏi nghi nghờ khả năng tích hợp mô hình quỹ tín thác trường đại học. Hơn $40 \%$ không chắc chắn về sự thành công của quỹ tín thác và khoảng $50 \%$ cho rằng quỹ tín thác trường đại học có thể sẽ khả thi tại môi trường đại học Việt Nam.

Không chỉ thế, trong số 45,5\% người đã từng biết đến quỹ tín thác trường đại học. Đa phần mọi người chỉ hiểu sơ lược về các vấn đề xoay quanh quỹ tín thác. Khoảng $42 \%$ đánh giá mức độ hiểu biết về mục đích của quỹ tín thác trường đại học ở mức rất thấp. Tương tự, khi được hỏi về cách thức vận hành, gần $60 \%$ hiểu một cách rất cơ bản. Không có ai cho rằng mình nắm rất rõ về mục đích và cách vận hành của quỹ tín thác trường đại học. Tương tự với quy tắc chi tiêu và lợi ích dài hạn của quỹ tín thác. $2 / 3$ số người được hỏi chỉ hiểu rất khái quát và cơ bản về các vấn đề này.

Sự thiếu hiểu biết về quỹ tín thác trường đại học là nguyên nhân chính khiến mọi người khó có thể đặt niềm tin vào hình thức tài trợ mới này. Hơn $63 \%$ người tham gia khảo sát lo ngại và thiếu tin tưởng về cách quản lý, vận hành quỹ tín thác. Đây cũng là nguyên nhân chính khiến mọi người ngần ngại khi được hỏi về khả năng quyền tặng, đóng góp cho quỹ tín thác trường đại học. Điều này sẽ gây ra nhiều khó khăn trong quá trình gây quỹ, giai đoạn nền tảng để triển khai mô hình quỹ tín thác trường đại học.

\section{vi) Những lỗ hổng trong hệ thống quản lý và pháp luật}

Hiện nay, cơ chế hoạt động cho trường không vì lợi nhuận chỉ mới vừa được ban hành theo Nghị định 141 Hướng dẫn thi hành một số điều của Luật giáo dục đại học. Năm 2018, Bộ Giáo dục và đào tạo chính thức ban hành Thông tư số 16/2018/TT-BGDĐT, quy định về tài trợ cho các cơ sở giáo dục thuộc hệ thống giáo dục quốc dân.

Tuy nhiên, các cơ sở giáo dục chưa có đủ thời gian để áp dụng những quy định này vào thực tiễn hoạt động và đánh giá hiệu quả của chúng. Vì vậy, việc xây dựng quỹ tín thác gặp nhiều khó khăn. Các khoản hiện tặng chủ yếu là những quỹ học bổng với quy mô không đáng kể.

Trong khi đó, các trường công lập lại chưa thể nào lập Quỹ Hiến tặng, do không có cơ chế tài chính để tạo hành lang pháp lý cho việc quản lý Quỹ. Quỹ Phát triển Đại học Quốc gia Thành phố Hồ Chí Minh là cơ quan duy nhất ở Việt Nam hiện nay được thành lập nhằm mục đích động viên các nguồn lực xã hội cho mục đích phát triển đại học. Tuy nhiên, có thể nói ảnh hưởng của quỹ này trong xã hội và trong giới sinh viên vẫn còn hạn chế.

Một lý do tạo ra những hạn chế đó là cơ chế nhà nước chưa khích lệ việc hiến tặng. Để xây dựng truyền thống hiến tặng, chính phủ các nước đều miễn thuế cho các khoản thu nhập dùng cho mục đích hiến tặng, và tạo ra nhiều hình thức khích lệ khác như cấp kinh phí đối ứng, tức là cứ mỗi đồng hiến tặng trường quyên góp được thì nhà nước cho thêm một đồng để lập thành một quỹ cho các hoạt động của nhà trường. Hai hình thức khích lệ này chưa hề có ở Việt Nam.

\section{5. Đề xuất một số giải pháp nhằm triển khai mô hình quỹ tín thác tại các trường đại học Việt Nam}

Để có thể triển khai mô hình quỹ tín thác tại Việt Nam cần có một số giải pháp cả ở cấp độ vĩ mô lẫn vi mô.

Thú $\boldsymbol{n}$ hất, thay đổi tư duy quản lý Nhà nước theo hướng Nhà nước chỉ quy định về khung 
trình độ quốc gia, chuẩn kỹ năng nghề nghiệp quốc gia để từ đó các cơ sở giáo dục đại học sẽ xây dựng mục tiêu đào tạo, chuẩn đầu ra cho người học đáp ứng các chuẩn nói trên, từ đó các cơ sở giáo dục đại học hoàn toàn tự chủ trong việc tổ chức đào tạo.

Thứ hai, đổi mới phương pháp quản lý nhà nước về giáo dục đại học theo hướng chuyển từ cơ chế quản lý tập trung sang phân cấp và mở rộng quyền tự chủ cho các trường đại học. Nhà nước nên thay đổi từ vai trò "người lái đò " sang vai trò định hướng cho sự phát triển, chuyển từ kiểm soát sang giám sát thông qua chính sách kiểm định chất lượng và phân bổ ngân sách. Có như vậy thì nhà nước vẫn đảm bảo được tính hiệu quả và hiệu lực trong việc thực thi vai trò quản lý của mình.

Thứ ba, rà soát, đánh giá sự phù hợp của Luật đầu tư công với cơ chế tự chủ Giáo dục đại học. Việc đầu tư cho các trường nên áp dụng cơ chế trọn gói và theo dự án. Các dự án quy mô lớn, cần sự hỗ trợ của nhà nước, Bộ Kế hoạch và Đầu tư cần hướng dẫn cơ sở Giáo dục đại học tự chủ đề xuất dự án đầu tư để thẩm định, tổng hợp vào kế hoạch đầu tư công trung hạn trình cấp có thẩm quyền phê duyệt theo quy định và hàng năm bố trí kế hoạch vốn đầu tư cho cơ sở Giáo dục đại học tự chủ để triển khai thực hiện.

Thứ tur, đẩy mạnh việc xây dựng, thành lập doanh nghiệp và tiến hành cổ phần hóa một số bộ phận phục vụ trong nhà trường. Xây dựng, thành lập doanh nghiệp là nhằm đổi mới chức năng, nhiệm vụ của trường đại học công lập, đó là vừa đào tạo, vừa nghiên cứu khoa học và tham gia phục vụ sản xuất kinh doanh. Thành lập các doanh nghiệp sẽ là cầu nối thúc đẩy việc chuyển giao các công trình nghiên cứu vào cuộc sống, nó làm cho các trường trở nên năng động hơn trong việc đáp ứng các nhu cầu của xã hội. Ở nước ngoài, việc thành lập doanh trong nhà trường là một tất yếu nhưng ở nước ta nó vẫn là một khái niệm xa lạ. Vì vậy, về phía các trường cần mạnh dạn thành lập doanh nghiệp với nhiệm vụ tư vấn, chuyển giao khoa học công nghệ, sản xuất kinh doanh các sản phẩm phục vụ đời sống xã hội. Về phía Nhà nước cần có chính sách hỗ trợ như miễn, giảm thuế cho các doanh nghiệp trong nhà trường. Ngoài ra, để tạo điều kiện cho các trường tập trung vào nhiệm vụ chính là đào tạo nghiên cứu khoa học thì Nhà nước nên cho phép cổ phần hoá một số khâu cung cấp dịch vụ như bộ phận ký túc xá, in ấn, thư viện, đào tạo ngắn hạn. Trong đó, cán bộ viên chức được ưu tiên mua cổ phần nhằm nâng cao hiệu quả hoạt động, hiệu quả quản lý thúc đẩy cán bộ viên chức tận tụy với sự phát triển của nhà trường.

Thứ năm, xây dựng thông tư hướng dẫn cụ thể về việc sử dụng các nguồn tài chính huy động được và các nguồn thu khác, đồng thời xác định những khoản cần đóng thuế, những khoản không cần đóng thuế. Xây dựng và hoàn thiện chính sách ưu đãi về thuế đối với các cơ sở Giáo dục đại học cũng như các chính sách ưu đãi đối với các đơn vị xã hội hóa theo Nghị định số 69/2008/NĐ-CP như miễn thuế giá trị gia tăng, thuế thu nhập doanh nghiệp đối với các khoản thu học phí, lệ phí,... Tiến hành việc giao tài sản cho các trường theo quy định của Luật số 09/2008/QH về quản lý, sử dụng tài sản nhà nước (sẽ được thay thế bởi Luật số $15 / 2017 / \mathrm{QH} 14$ về quản lý sử dụng tài sản công có hiệu lực thi hành từ $01 / 01 / 2018$ ) để nhà trường có thể chủ động trong việc liên doanh, liên kêt, góp vốn với các đơn vị, tổ chức khác. Hình thành công ty quản lý vốn nhà nước tại các cơ sở Giáo dục đại học công lập để bảo toàn vốn tại các cơ sở giáo dục công lập (giống như cách làm khi bãi bỏ cơ chế chủ quản của doanh nghiệp nhà nước trước đây).

Thút sáu, xây dựng cơ chế/quy định về việc sử dụng tài sản công của các cơ sở Giáo dục đại học công lập khi thành lập các đơn vị liên doanh, liên kết với các tổ chức, cá nhân, doanh nghiệp khác để tổ chức các hoạt động sản xuất, kinh doanh, dịch vụ gắn với đào tạo theo nguyên tắc bảo toàn vốn, tài sản nhà nước, bù đắp chi phí và có tích lũy.

Thứ bảy, đẩy mạnh tuyên truyền, phổ biến nhằm đổi mới nhận thức, tạo sự đồng thuận xã hội, xác định chỉ cho giáo dục đại học là chủ đầu tư phát triển. Cuộc cách mạng khoa học công nghệ đang diễn ra hàng ngày, hàng giờ trên thế giới đã làm đảo lộn vai trò của các yếu tố truyền thống trong sản xuất và cạnh tranh. Khoa học công nghệ trở thành lực lượng sản xuất trực tiếp, 
trí tuệ là nguồn lực nội sinh cho sự phát triển của một quốc gia. Vì vậy, ở nước ta cần nâng cao chất lượng các trường đại học công lập, đảm bảo mỗi nhà trường thực sự là một trung tâm sản sinh ra tri thức mới đáp ứng nhu cầu phát triển kinh tế - xã hội của đất nước. Song, tri thức của một nhà trường không ngẫu nhiên mà có, nó chỉ được tạo ra khi giải quyêt được đồng thời ba vấn đề: Đội ngũ cán bộ, giảng viên phải vừa đổi mới vừa chuyên sâu; phương pháp đào tạo, cơ sở vật chất, giáo trình, giáo án, bài giảng phải cập nhật những công nghệ, kiến thức mới đáp ứng yêu cầu của các đơn vị, doanh nghiệp sử dụng sản phẩm đào tạo; tuyển chọn người học có đủ trình độ, năng lực và say mề với ngành nghề được đào tạo. $\mathrm{Ba}$ vấn đề trên có sự gắn kết hữu cơ với nhau, nó được giải quyết khi nhà trường có đủ nguồn lực tài chính, đặc biệt là có cơ chế tự chủ tài chính linh hoạt, phù hợp với hoàn cảnh, thời điểm cụ thể. Trong điều kiện Nhà nước còn khó khăn về ngân sách đầu tư cho giáo dục đại học thì xã hội hóa là một yêu cầu khách quan, đảm bảo giáo dục đại học có cơ hội phát triển, hội nhập quốc tế ở cấp độ vĩ mô, các trường đại học cần tăng cường tuyên truyền, phổ biến rộng rãi trên các phương tiện thông tin truyền thông để thay đổi nhận thức của toàn thể cộng đồng là đầu tư giáo dục đại học là đầu tư cho sự phát triển.

Thứ tám, xác định mục tiêu của việc thành lập quỹ tín thác không phải là lợi nhuận. Nếu những người hoạt động gây quỹ xem tiền là mục tiêu, và tất cả những sự kiện mà họ tổ chức là phương tiện, sớm muộn gì những người đóng góp cũng sẽ nhận ra điều ây. Điều cốt lõi nhất là chia sẻ tầm nhìn của nhà trường, làm cho xã hội hiểu rõ và trân trọng những giá trị của nhà trường cũng như ý nghĩa của những đóng góp mà nhà trường đem lại cho xã hội. Điểm trọng yếu tạo hiệu quả lâu dài cho quỹ tín thác là quan hệ và uy tín, những thứ phải xây dựng qua thời gian. Để làm được việc đó, hội đồng gây quỹ cần kiên trì xây dựng mạng lưới cựu sinh viên, hoàn toàn không hối thúc sự đóng góp của họ, tạo ra những kênh thông tin và truyền thông, những ấn phẩm, sinh hoạt xã hội, giúp mọi người duy trì mối quan hệ với nhà trường, hiểu được những gì đang diễn ra, những việc nhà trường đang làm và những việc đó có ý nghĩa như thế nào trong việc xây dựng một tương lai tốt đẹp hơn. Những người quản lý quỹ cần quan tâm đến từng chi tiết nhỏ, vì mỗi một chi tiết đều có ý nghĩa. Hoạt động gây quỹ cần phải chuyên nghiệp, bàn bản, có phương hướng, đường lối chi tiêu rõ ràng.

Thứ chín, không ngừng học hỏi, nghiên cứu. Có thể thấy, quỹ tín thác trường đại học không phải là một mô hình mới trên thế giới. Không chỉ ở Hoa Kỳ mà nhiều quốc gia, khu vực của Châu Á như Singapore, Hồng Kông cũng đã triển khai quỹ tín thác trường đại học. Vì vậy, lãnh đạo của các cơ sở giáo dục đại học công lập tại Việt Nam cần hết sức quan tâm đến những mô hình đang tồn tại trong khu vực, xây dựng đội ngũ nòng cốt nhằm nghiên cứu, phân tích những điểm mạnh, điểm yếu của chúng để áp dụng với từng trường hợp cụ thể.

Thứ mười, nâng cao hiệu quả của công tác vận động tài trợ bằng cách nghiên cứu sâu rộng về đối tượng tài trợ, xây dựng và triển khai kế hoạch vận động tài trợ thống nhất, đồng bộ trong toàn hệ thống; tích cực tiếp cận và vận động tài trợ tạo nguồn lực phát triển ổn định và bền vững cho các trường đại học. Cần đặt mục tiêu tạo ra một mối quan hệ lâu dài vì những mục đích và lợi ích chung cho sự phát triển của giáo dục và sự hoàn thiện của nguồn nhân lực trẻ. Cùng với đó, các nhà trường nên tích cực truyền thông quảng bá xây dựng thương hiệu của riêng mình, kết nối, gắn kết chặt chẽ giữa đại học và doanh nghiệp, phát triển và phát huy vai trò của cựu sinh viên. Xây dựng mạng lưới quan hệ, truyền thông tích cực, xây dựng hình ảnh quỹ tín thác và hình thành văn hóa cho-tặng cho phát triển đại học. Xây dựng mối quan hệ gắn kết chặt chẽ giữa doanh nghiệp và nhà trường có chú trọng đến việc xây dựng các mối quan hệ thông qua mạng lưới các thế hệ cựu sinh viên và sinh viên trong trường để cùng hợp tác, phát triển.

Thú mười một, tăng cường và phát triển mạnh, bền vững nguồn lực tài chính. Để thực hiện điều này, các trường đại học cần tập trung xây dựng mô hình đầu tư và tạo nguồn tài chính ổn định và bền vững, xây dựng mô hình quỹ trường tồn, triển khai mạnh các hoạt động đầu tư, dịch vụ, sử dụng hiệu quả các nguồn lực tài chính, phục vụ nỗ lực cho giáo dục đại học: hỗ 
trợ tích cực và hiệu quả hoạt động học tập, giảng dạy, nghiên cứu khoa học của trường.

Thứ mười hai, phát triển nguồn nhân lực, hoàn thiện bộ máy, nâng cao năng lực quản trị bộ máy tại từng cơ sở. Điều này có thể thực hiện bằng cách hoàn thiện và nâng cao tính chuyên nghiệp của bộ máy quản trị; phát huy lợi thế, vai trò của các thành viên Hội đồng Quản lý. Xây dựng mô hình với cơ cấu bộ máy tinh gọn, hiệu quả, có chú trọng yếu tố nhân sự chuyên môn trong lĩnh vực quản lý tài chính, ngân hàng. Bộ máy gồm Hội đồng Quản lý Quỹ (có số lượng và cơ cấu thành phần thích hợp), Bộ máy quản lý điều hành (nhân sự có chuyên môn về công tác điều hành, quản lý quỹ). Thành lập mới các bộ phận chuyên về lĩnh vực đầu tư dịch vụ.

\section{Kết luận}

Thành công của các mô hình quỹ tín thác trường đại học Hoa Kỳ đến từ sự tồng hòa của nhiều yếu tố. Cần chú ý đặc biệt đến vấn đề làm thế nào để thu hút các nhà tài trợ tiềm năng, bởi đây là một trong những cột mốc cho sự thành lập và phát triển của quỹ tín thác. Vì khái niệm quỹ tín thác trường đại học còn rất mới lạ với người Việt Nam, chúng ta cần học hỏi kinh nghiệm của các trường đại học lớn nhất thế giới, đặc biệt là các trường đại học Hoa Kỳ, vốn đã có nhiều thập kỷ xây dựng và vận hành thành công quỹ tín thác. Một vấn đề cốt lõi nữa của mô hình quỹ tín thác đại học Hoa Kỳ chính là quan hệ và tương tác hiệu quả với nhiều đối tượng tài trợ, từ cựu sinh viên, phụ huynh học sinh, sinh viên đến các công ty, tổ chức, tập đoàn. Do đó, xây dựng một hệ thống gây quỹ giáo dục tại các trường đại học tại Việc Nam và thiết lập các khoản tài trợ có khả năng trở thành động lực cho sự phát triển, đổi mới của nghiên cứu và giáo dục, đồng thời đặt ra những thách thức mới cho các cơ sở đào tạo bậc cao trong kỉ nguyên mới. Nếu chỉ là xác định các hình thức vận hành mới hay bổ sung thêm một cách để thu thập nguồn lực từ cựu sinh viên, tổ chức, cơ quan, công ty và nền tảng, thì quỹ tín thác trường đại học sẽ không thể tồn tại lâu dài. Trên thực tế, các cán bộ phát triển đại học nên tìm ra các công cụ phương pháp để quản lý các khoản tài trợ như nguồn lực đầu tư dài hạn.

Đóng góp từ các công ty, tổ chức và cá nhân, chẳng hạn như cựu sinh viên, bạn bè, phụ huynh và giảng viên của trường đại học vừa xây dựng phong trào hiến tặng cho giáo dục, vừa mở ra nhiều cơ hội cho sinh viên ngày nay. Giáo dục đại học với định hướng chung của Bộ Giáo dục và đào tạo là "tiếp tục đẩy mạnh thực hiện tự chủ, nâng cao chất lượng đào tạo và nghiên cứu khoa học, hỗ trợ khởi nghiệp cho sinh viên,...", các loại quỹ phục vụ giáo dục là một công cụ thiết yếu để cải thiện nguồn lực chiến lược cho phát triển kinh tế xã hội, văn hóa và tinh thần, thiết lập các điều kiện cho sự tự nhận thức của mỗi cá nhân. Điểu này là đặc biệt quan trọng trong quá trình hội nhập giữa Việt Nam với các nước trong khu vực cũng như trên khắp thế giới. Các trường đại học công lập Việt Nam sẽ cần áp dụng những mô hình thực tiễn có hiệu quả rõ ràng của các trường đi trước, đồng thời, tránh vấp phải những sai lầm trong quá trình gây quỹ cũng như quản lý quỹ và ngay cả những rủi ro của sự phát triển của chương trình giáo dục và nghiên cứu của mình. Quỹ tín thác trường đại học sẽ cho phép các cơ sở đào tạo bậc cao đáp ứng tốt hơn những thách thức mà nền giáo dục hiện tại đang gặp phải. Từ thiện trong giáo dục bậc cao giúp thu hút và duy trì đội ngũ giảng viên giỏi nhất, tăng hỗ trợ học bổng, thành lập và tài trợ cho các trung tâm nghiên cứu, đảm bảo cơ sở vật chất tiên tiến và bảo đảm cân đối tài chính lâu dài của trường đại học. Đầu tư tốt và tài trợ mạnh mẽ cho phép các nhà tài trợ tạo ra một di sản vĩnh viễn và giải phóng tiềm năng vô tận của giáo dục. Hơn thế nữa, những giá trị tích cực này sẽ được nhân lên đáng kể theo thời gian.

Nhận thấy tính khả thi và những lợi ích của mô hình quỹ tín thác trường đại học Hoa Kỳ, người viết cho rằng để có thể áp dụng mô hình tại các trường đại học Việt Nam trong điều kiện tự chủ là nghiên cứu thêm nhiều phương án để tối ưu hóa sự phát triển của quỹ tín thác trong từng trường hợp cụ thể với cách quản lý, tổ chức, nguồn lực tài chính của từng trường đại học. Đây sẽ là tiền đề quan trọng để thực hiện quyền tự 
chủ trong các cơ sở giáo dục bậc cao theo đường hướng phát triển của Nhà nước.

\section{Tài liệu tham khảo}

[1] H. Henry, Why do universities have endowments?, The Journal of Legal Studies 19 (1990) 3-42. https://doi.org/10.1086/467841.

[2] K. Alla, Endowment as an Educational Fundraising Tool for Entrepreneurial University: the US Experience versus Ukrainian Reality and Perspectives, Kultura-Społeczeństwo-Edukacja 6 (2014), 57-73. https://doi.org/10.14746/kse.2014.6.2.04

[3] D. Noah, Philanthropy and fundraising in American higher education, John Wiley \& Sons, 2011.

[4] J.L. Yeager, G.M. Nelson, E.A. Potter, J.C. Weidman, T.G. Zullo, Finance in Higher Education, Pearson Custom Publishing, Boston, (2001) 90-95.

[5] J.D Moore, A study of university endowments: Size, performance, and allocation, Ohio University, 2017. http://rave.ohiolink.edu/etdc/view?acc_num=ouho nors 1492782291165007

[6] B. Richard, Investing Like the Harvard and Yale Endowment Funds, Advisor Perspective, 1 (2008).

[7] American Council On Education, Understanding college and university endowments. https://www.acenet.edu/Documents/Understandin g-Endowments-White-Paper.pdf, 2014 (accessed 15/04/2020)

[8] C.T. Clotfelter, M. Rothschild, Studies of supply and demand in higher education, University of Chicago Press, 2008.

[9] J.J. Fishman, What went wrong: Prudent management of endowment funds and imprudent investing policies, The Journal Of College And University Law, $40 \quad$ (2014) 199. https://core.ac.uk/download/pdf/46714341.pdf [Accessed 01/05/2019]

[10] H. Hamdino, M. Anifowose, H. A. Annuar, Effective Board Governance Structure for a University Endowment Fund, Islamic Development Management, 2019, 3-17. https://doi.org/10.1007/978-981-13-7584-2_1

[11] C. Georg et al, A survey of university endowment management research, Journal of Investment Management 3 (2014), Journal of Investment Management.

https://dx.doi.org/10.2139/ssrn.2205207
[12] Harvard University, Harvard University Financial Report: Fiscal Year 2018. https://finance.harvard.edu/files/fad/files/harvard_ annual_report_2018_final.pdf (Accessed 01/05/2019)

[13] J. Heather, How Harvard Raised \$9.6 Billion, and What Comes Next for All Campaigns, 2018. https://www.philanthropy.com/article/How-

Harvard-Raised-

96/244716?fbclid=IwAR2nKEyJrF7LTspbQb4a1O9 RKalQJu3YETpZewWgBPdfLglH4QNPDnhoFcE

[14] D. Elza, Managing Endowment Fund Income in Universities, Educational Studies, Higher School of Economics, 2016, 225-244. https://doi.org/10.17323/1814-9545-2016-1-225244

[15] Stanford University, Stanford University Financial Report: Fiscal Year 2018. https://bondholderinformation.stanford.edu/pdf/SU_AnnualFinancial Report_2018.pdf (Accessed 02/05/2019)

[16] D.N. Anh, Social charity in the community scale in Vietnam, Journal of Sociology, 4 (2015), 132. https://asiafoundation.org/resources/pdfs/ASIAEfi nal.pdf

[17] D.N. Anh, L.K. Sa, N.T. Thuy, N.V. Lang, P.H. Nam, Philanthropy in Vietnam, Asia Pacific Economics Center, 2011. https://asiafoundation.org/resources/pdfs/ASIATV final.pdf 9 (Accessed 01/05/2019).

[18] D.H. Giang, P.M. Tri, Enterprises's charitable contribution and the perspective of nongovermental sector, The Asian Foudation and Vietnam Chamber of Commerce and Industry, 2013.

https://asiafoundation.org/resources/pdfs/TAFCS OReportVnFinal.pdf (Accessed 01/05/2019)

[19] National Financial Supervision Commission, Brieft report on Vietnam financial market 2018. http://nfsc.gov.vn/wpcontent/uploads/2018/12/BC-Public$\mathrm{t} \% \mathrm{E} 1 \% \mathrm{BA} \% \mathrm{~A} 1 \mathrm{i}-\mathrm{H} \% \mathrm{E} 1 \% \mathrm{BB} \% 99 \mathrm{i}-$ th\%E1\%BA\%A3o-v\%C3\%A0-website\%E1\%BB\%A6y-ban_191218.pdf (Accessed 05/05/2019).

[20] V.H. Phong, H.A. Dung, L.Q. Binh, P.T. Tra, Citizens 'awareness of charitable activities and the fund raising competence of non-governmental orgainzations in Vietnam, The Institute for Study of Society, Economics and Environment, Transport Publishing House, 2015. http://isee.org.vn/Content/Home/Library/467/nhan -thuc-cua-nguoi-dan-ve-hoat-dong-tu-thien-vakha-nang-gay-quy-cua-cac-to-chuc-phi-chinhphu-viet-nam..pdf (Accessed 01/05/2019) 